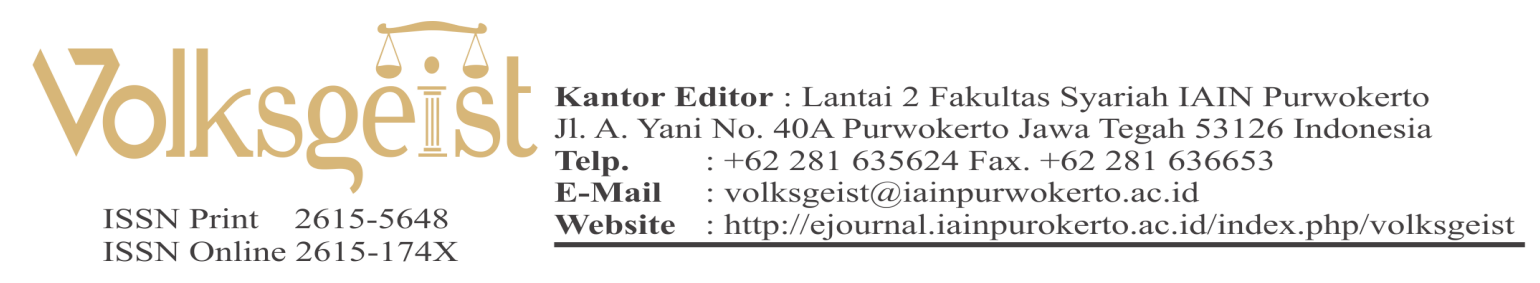

\title{
Urgensi Pembentukan Undang-Undang tentang Majelis Permusyawaratan Rakyat
}

\author{
Harry Setya Nugraha \\ Fakultas Hukum Universitas Mulawarman \\ Email: Harrysetyanugraha@fh.unmul.ac.id
}

\begin{abstract}
Abstark
Artikel ini disusun dengan tujuan untuk menjawab urgensi pembentukan undang-undang tentang MPR dalam sistem ketatanegaraan Indonesia. Metodologi yang digunakan adalah metode penelitian yuridis normatif, dengan pendekatan perundang-undangan, dan konseptual, serta analisis dilakukan secara deskriptif kualitatif. Artikel ini berkesimpulan bahwa pertama, pembentukan undang-undang tentang MPR memiliki urgensi secara filosofis, yuridis, maupun sosiologis-politik. Kedua, proses pembentukan undang-undang tentang MPR harus memperhatikan proses pembentukan dan materi muatan pembentukan peraturan perundang-undangan yang baik sebagaimana diatur dalam ketentuan peraturan perundang-undangan.
\end{abstract}

Kata Kunci: Undang-undang, MPR, lembaga negara

\section{Abstract}

This article aims to answer the urgency of the formation of Law about MPR in the Indonesian constitutional system. This research uses normative juridical research method with statutory and conceptual approach, as well as a qualitative descriptive analysis. This article concludes that 1) the formation of law on MPR has philosophical, juridical, and socio-political urgency; 2) the process of forming the law regarding the MPR must pay attention to the process and the content of the formation of good laws and regulations as regulated in the legislations.

Keywords: law, people's consultative assembly, state organ

\section{Sejarah Artikel}

Dikirim: 24 Maret 2021

Direview: 13 Juni 2021

Diterima: 16 Juni 2021

Diterbitkan: 23 Juni 2021

\section{PENDAHULUAN}

Sepanjang perjalanan sistem ketatanegaraan di Indonesia yang terhitung sejak kemerdekaan Republik Indonesia hingga saat ini, satu dari sekian banyak lembaga negara yang mendapatkan banyak sorotan publik oleh karena kedudukan dan kewenangannya dalam sistem ketatanegaraan Indonesia adalah Majelis Permusyawaratan Rakyat (MPR). Bagaimana tidak, dalam sejarahnya (sebelum reformasi), MPR dalam konteks yang global dapat dikatakan sebagai lembaga negara yang "unik". ${ }^{1}$ Unik dalam hal ini dikarenakan

1 Putera Astomo, Hukum Tata Negara Teori Dan 
MPR merupakan lembaga perwakilan yang kedudukannya berada di atas parlemen (Dewan Perwakilan Rakyat). Biasanya, parlemen dianggap sebagai satu-satunya wadah yang mencakup wakil-wakil yang dipilih dalam suatu pemilihan umum. Akan tetapi, "wakil rakyat" dalam MPR terdiri dari anggota, baik yang dipilih dalam suatu pemilihan umum maupun mencakup anggota yang diangkat. ${ }^{2}$

Selain keunikan dalam hal keanggotaan, MPR juga memiliki keunikan lain berkenaan dengan kelembagaan dan kewenangannya dalam sistem ketatanegaraan Indonesia. Ketika itu, MPR merupakan satu-satunya lembaga tertinggi negara yang memiliki kewenangan penuh dalam melaksanakan kedaulatan rakyat. Penyebutan MPR sebagai lembaga tertinggi negara saat itu didasarkan pada bunyi Pasal 1 ayat (2) Undang-Undang Dasar (UUD) Tahun 1945 yang asli $^{3}$ dan bunyi Penjelasan pada bagian Sistem Pemerintahan Negara butir III yang menggariskan bahwa "Kekuasaan Negara yang tertinggi di tangan Majelis Permusyawaratan Rakyat", yang kemudian diatur juga dalam Ketetapan MPRS Nomor XX/MPRS/1966. ${ }^{4}$

Namun pasca reformasi (tepatnya dalam Sidang Tahunan 2001), MPR memutuskan untuk menyempurnakan Pasal 1 ayat (2) UUD 1945 lama dan menggantinya menjadi "Kedaulatan berada di tangan rakyat dan dilakukan menurut UUD”. Perubahan tersebut mengisyaratkan bahwa kedudukan MPR tidak lagi sebagai lembaga tertinggi negara dan tidak lagi memegang kedaulatan rakyat sebagaimana diatur dalam Pasal 1 ayat (2) UUD $1945 .{ }^{5}$

Praktek (Yogyakarta: Thafa Media, 2014). 153.

2 Astomo.

3 "Undang-Undang Dasar Negara Republik Indonesia Tahun 1945," n.d.

4 Moh Mahfud MD, Perdebatan Hukum Tata Negara Pasca Amandemen Konstitusi, Cet 1 (Jakarta: Raja Grafindo Persada, 2010). 31.

5 Ni'matul Huda, Lembaga Negara Dalam Masa Transisi Demokrasi (Yogyakarta: UII Press, 2007). 95.
Dengan kata lain, MPR pasca perubahan UUD 1945 merupakan lembaga negara yang sederajat dengan lembaga-lembaga negara lainnya seperti: Presiden, Dewan Perwakilan Rakyat (DPR), Badan Pemeriksa Keuangan (BPK), Mahkamah Agung (MA), Mahkamah Konstitusi (MK), dan Komisi Yudisial (KY). ${ }^{6}$

Perubahan kedudukan tersebut juga berimplikasi pada kewenangan dan keanggotaan MPR. Dalam hal kewenangan, MPR kini tidak lagi berwenang memilih Presiden dan Wakil Presiden, tidak lagi berwenang memberhentikan Presiden dan/atau Wakil Presiden dalam masa jabatannya selama tidak ada usulan dari DPR setelah MK memeriksa, mengadili dan memutuskan bahwa Presiden dan/atau Wakil Presiden bersalah, serta tidak lagi berwenang membuat dan menetapkan GBHN. ${ }^{7}$ Wewenang yang masih melekat pada MPR adalah mengubah dan menetapkan Undang-Undang Dasar Negara Republik Indonesia Tahun $1945^{\circ}$ (UUD NRI 1945)9 ${ }^{9}$, melantik Presiden dan/ atau Wakil Presiden, ${ }^{10}$ dan memberhentikan

6 Dapat dilihat dalam Pasal 10 "Undang-Undang Nomor 22 Tahun 2003 Tentang Susunan Dan Kedudukan MPR, DPR, DPD Dan DPRD," n.d. "MPR merupakan lembaga permusyawaratan rakyat yang berkedudukan sebagai lembaga negara". Demikian pula dalam Ketetapan MPR Nomor II/MPR/2003 tentang Perubahan Kelima Atas Ketetapan MPR Nomor II/MPR/1999 tentang Peraturan Tata Tertib MPR Pasal 2 Ketetapan MPR Nomor II.MPR/1999 yang semula berbunyi "Majelis adalah penjelmaan seluruh rakyat Indonesia dan merupakan lembaga tertinggi negara, pemegang dan pelaksana sepenuhnya kedaulatan rakyat", diubah menjadi selengkapnya berbunyi "Majelis adalah lembaga negara, pemegang, dan pelaksana kedaulatan rakyat menurut ketentuan Undang-Undang Dasar Republik Indonesia Tahun 1945".

7 "Undang-Undang Dasar Negara Republik Indonesia Tahun 1945." (UUD NRI 1945) adalah penyebutan bagi Undang-Undang Dasar Tahun 1945 hasil perubahan.

8 Huda, Lembaga Negara Dalam Masa Transisi Demokrasi. 95.

9 Pasal 3 ayat (1) "Undang-Undang Dasar Negara Republik Indonesia Tahun 1945."

10 Pasal 3 ayat (2) "Undang-Undang Dasar Negara Republik Indonesia Tahun 1945.” 
Presiden dan/atau Wakil Presiden dalam masa jabatannya menurut UUD. ${ }^{11}$ Sementara dalam hal keanggotaan, yang semula MPR terdiri atas anggota-anggota DPR ditambah dengan utusanutusan dari daerah-daerah dan golongangolongan menurut aturan yang ditetapkan dengan undang-undang, kini keanggotaan MPR terdiri dari anggota DPR dan anggota DPD yang dipilih melalui pemilihan umum dan diatur lebih lanjut dalam undang-undang. ${ }^{12}$

Terlepas dari perbedaan konstruksi dasar kelembagaan dan kewenangan MPR tersebut, perlu untuk diketahui bahwa pengaturan lebih lanjut berkenaan dengan kelembagaan dan kewenangan MPR baik sebelum maupun setelah reformasi "selalu" diatur dalam satu undang-undang organik yang pengaturannya "dipaketkan" bersamaan dengan pengaturan kelembagaan dan kewenangan Dewan Perwakilan Rakyat (DPR), Dewan Perwakilan Rakyat Daerah(DPRD) serta Dewan Perwakilan Daerah (setelah perubahan UUD NRI 1945). ${ }^{13}$

Pengaturan kelembagaan MPR yang selalu "dipaketkan" dalam suatu undang-undang yang juga mengatur kelembagaan lain menimbulkan suatu permasalahan, karena Pasal 2 ayat (1) UUD NRI 1945 secara tegas menyebutkan bahwa MPR terdiri atas anggota DPR dan DPD yang dipilih melalui pemilu dan diatur lebih lanjut dengan undang-undang. Menyadari

\footnotetext{
11 Pasal 3 ayat (3) "Undang-Undang Dasar Negara Republik Indonesia Tahun 1945."

12 Pasal 2 ayat (1) "Undang-Undang Dasar Negara Republik Indonesia Tahun 1945."

13 Sejak didirikan, kelembagaan MPR selalu diatur dalam undang-undang yang juga mengatur mengenai lembaga negara lainnya. Hal ini dapat dilihat dari historical pengaturan kelembagaan MPR mulai dari "UndangUndang Nomor 16 Tahun 1969 Tentang Susunan Dan Kedudukan Majelis Permusyawaratan Rakyat, Dewan Perwakilan Rakyat, Dan Dewan Perwakilan Rakyat Daerah," n.d. hingga Undang-Undang Nomor 42 Tahun 2014 tentang Perubahan Atas Undang-Undang Nomor 17 Taun 2014 tentang Majelis Permusyawaratan Rakyat, Dewan Perwakilan Rakyat, Dewan Perwakilan Daerah, dan Dewan Perwakilan Rakyat Daerah yangs elanjutnya disebut dengan UU MD3.
}

permasalahan sebagaimana dimaksud, perlu saat ini mulai difikirkan suatu upaya guna memisahkan pengaturan kelembagaan dan kewenangan MPR dengan undang-undang tersendiri.

Berkenaan dengan hal tersebut, artikel ini akan membahas urgensi pemisahan pengaturan kelembagaan dan kewenangan MPR dengan undang-undang tersendiri atau dengan kata lain urgensi pembentukan Undang-Undang tentang MPR, baik secara filosofis, yuridis maupun sosiologis-politik. Selain itu, akan dibahas pula beberapa hal yang perlu diperhatikan dan menjadi catatan dalam upaya pembentukan undang-undang a quo.

Dengan mengusung pendekatan perundang-undangan dan konseptual, sudut pandang yang penulis kedepankan dalam artikel ini pada dasarnya berbeda dengan artikelartikel lain yang apabila berbicara mengenai kelembagaan MPR lebih banyak berbicara soal kedudukan produk hukum maupun penguatan kelembagaan MPR. Dalam artikel yang ditulis oleh Saifudin dan Dessy Ariani misalnya, artikel tersebut berbicara mengenai kajian yuridis eksistensi dan materi ketetapan MPR dalam hirarki perundang-undangan di Indonesia dengan fokus kajian pada kedudukan TAP MPR dan lembaga yang dapat menguji TAP MPR. ${ }^{14}$

Sementara artikel yang berbicara mengenai penguatan kelembagaan MPR diantaranya adalah artikel yang ditulis oleh Putu Ayu Anastasia Wierdarini yang berjudul "Tinjauan Yuridis Terhadap Pengembalian Kewenangan Istemewa MPR Melalui Perubahan UUD NRI Tahun 1945", ${ }^{15}$ dan artikel yang ditulis

14 Saifudin Saifudin and Dessy Ariani, "Kajian Yuridis Eksistensi Dan Materi Ketetapan Majelis Permusyawaratan Rakyat Republik Indonesia Dalam Hirarki Perundang-Undangan Di Indonesia," Jurnal Hukum Ius Quia Iustum 22, no. 1 (2015): 142-62, https:// doi.org/10.20885/iustum.vol22.iss1.art7.

15 Putu Ayu Anastasia Wierdarini, "Tinjauan Yuridis Terhadap Pengembalian Kewenangan Istimewa Majelis Permusyawaratan Rakyat Melalui Perubahan 
oleh Rizki Ramadani yang berjudul "Gagasan Penyempurnaan Lembaga MPR RI dalam Sistem Parlemen Dua Kamar", serta berbagai artikel lainnya. ${ }^{16}$

Perbedaan sudut pandang yang penulis kedepankan cukup memperlihatkan arti penting tulisan ini sebagai bagian dari pengayaan ilmu pengetahuan, khususnya di bidang Hukum Tata Negara.

\section{PEMBAHASAN}

\section{Urgensi Filosofis Pembentukan UU MPR}

Setidaknya ada dua pandangan yang mengemuka kepermukaan jika kita berbicara mengenai landasan filosofis berkenaan dengan pentingnya suatu peraturan perundang-undangan. Pertama, pandangan yang menyatakan bahwa landasan filosofis adalah landasan yang berkaitan dengan dasar atau ideologi negara, yaitu nilai-nilai (cita hukum) yang terkandung dalam Pancasila. Pendapat ini di antaranya dianut oleh Jimly Asshiddiqie. ${ }^{17}$ Kedua, pandangan yang menyatakan bahwa landasan filosofis adalah pandangan atau ide pokok yang melandasi seluruh isi peraturan perundangundangan. Pendapat ini dianut oleh Solly Lubis yang menyatakan bahwa landasan filosofis suatu peraturan perundang-undangan adalah dasar filsafat atau pandangan, atau ide yang menjadi dasar cita-cita sewaktu menuangkan hasrat dan kebijaksanaan (pemerintahan) ke dalam suatu rencana atau draft peraturan Negara. ${ }^{18}$ Untuk keluar dari perbedaan kedua pandangan tersebut,

Undang-Undang Dasar Negara Republik Indonesia Tahun 1945," Jurnal Yuridis 5, no. 1 (2018).

16 Rizki Ramadani, "Gagasan Penyempurnaan Lembaga Majelis Permusyawaratan Rakyat Republik Indonesia Dalam Sistem Parlemen Dua Kamar," Pleno Jure 9, no. 1 (2020): 1-15, https://doi.org/10.37541/ plenojure.v9i1.305.

17 Jimly Asshiddiqie, Perihal Undang-Undang (Jakarta: Konstitusi Press, 2006). 169.

18 M Solly Lubis, Landasan Dan Teknik Perundang-Undangan (Bandung: CV Mandar Maju, 1989). maka ada baiknya mengakomodir keduanya. Sebab berdasarkan kaidah hukum, al-khuruj minal khilaf mustahabbun, artinya keluar dari perbedaan lebih dianjurkan. ${ }^{19}$ Dengan demikian tidak terjebak di dalam perbedaan tentu jauh lebih diutamakan.

Lebih lanjut berbicara mengenai urgensitas secara filosofis pembentukan UndangUndang tentang MPR, perlu untuk diketahui terlebih dahulu bahwa secara keseluruhan, UUD 1945 sebelum perubahan mengenal 6 (enam) lembaga tinggi/tertinggi negara, yaitu MPR, DPR, Presiden, MA, BPK dan DPA. Dari enam lembaga negara tersebut, hanya MPR saja yang bersifat khas Indonesia. Lima lainnya berasal dari cetak biru kelembagaan yang dicontoh dari zaman Hindia Belanda. DPR dapat dikaitkan dengan sejarah Volksraad (Dewan Rakyat), Presiden tidak lain adalah pengganti lembaga Gouvernuur General, MA berkaitan dengan Landraad dan Raad van Justice di Hindia Belanda, serta Hogeraad yang ada di negeri Belanda. BPK berasal dari Raad van Rekenkammer, dan DPA berasal dari Raad van Nederlandsche Indie yang ada di Batavia atau Raad van State di negeri Belanda. Sedangkan MPR yang mempunyai kedudukan sebagai lembaga tertinggi negara tidak ada contohnya, kecuali ada di lingkungan negaranegara komunis yang menetapkan sistem partai tunggal, dimana kedaulatan rakyat disalurkan ke dalam pelembagaan Majelis Rakyat yang tertinggi (supreme people's council) seperti di Uni Soviet, di Republik Rakyat Cina dan lainlain. $^{20}$

Konsep kelembagaan negara yang diterapkan di Indonesia dengan memposisikan MPR sebagai satu-satunya lembaga tertinggi

19 Muhammad Bakar Ismail, Al-Qawa'idh AlFiqhiyyah Baina Al-Ashalati Wa Al-Taujih (Kairo: Darul Manar, 1996). 126

20 Jimly Asshiddiqie, Konstitusi Dan Konstittusionalisme Indonesia (Jakarta: Sekretariat Jenderal dan Kepaniteraan MK, 2006). 168. 
negara ketika itu praktis membuat tidak sedikit kritikus yang berpandangan bahwa sistem kenegaraan yang dipraktikkan di Indonesia adalah sesuatu sistem yang "banci", sistem parlemen bukan dan presidensilpun tidak sepenuhnya. Dari hal tersebut, lantas muncul pertanyaan tentang "mengapa para pendiri negara tidak memilih salah satu model yang sudah ada di dunia, yaitu Amerika Serikat, model demokrasi parlemen di Eropa Barat, model presidensil ala Amerika Latin, atau model demokrasi rakyat ala Uni Soviet?" Perlu diketahui bahwa tidak sedikit negara yang baru merdeka setelah Perang Dunia ke II memilih satu dari model-model tersebut, tetapi Indonesia justru tidak memilih model yang telah berkembang di dunia, melainkan merancang suatu model sistem yang khas yang kemudian dikenal sistem UUD 1945 dengan MPR sebagai lembaga tertinggi negara. ${ }^{21}$

Berkenaan dengan hal tersebut, nampaknya pendiri negara sadar bahwa negara yang dibangun di seberang jalan emas haruslah negara yang stabil. Karena itu, perlu dirancang suatu sistem politik yang menjamin stabilnya penyelenggaraan negara tersebut. Sampai dengan saat pendiri negara merancang UUD 1945, sejarah menunjukkan bahwa sistem demokrasi parlementer sangatlah labil, praktik kinerja legislatif saling menjatuhkan (lihat Prancis dan Italia), sebaliknya, sistem presidensil (Presiden dipilih langsung) sering melahirkan pemerintahan yang diktator, seperti Peron di Argentina atau Jerman dalam periode Republik Weimar yang melahirkan Hitler. Fakta sejarah inilah yang menjadi salah satu latar belakang pemikiran mengapa pendiri negara memilih jalan ketiga yaitu sistem semi Presidensil yang mengatur adanya MPR sebagai lembaga tertinggi negara. ${ }^{22}$

21 Soedijarto, "Implikasi Ajaran Pendiri Republik (Bung Karno) Dan Budaya Politik Indonesia Terhadap Amandemen UUD 1945" (Yogyakarta, 2016). 36.

22 Soedijarto.
Di samping alasan tersebut, pilihan pendiri negara untuk tidak menjadikan Amerika dan Eropa Barat sebagai role model ketatanegaraan Indonesia hingga akhirnya membentuk kelembagaan MPR sebagai lembaga tertinggi negara juga didasari atas penolakan mereka terhadap faham liberalisme dan demokasi Barat. $^{23}$ Dikatakan oleh M. Yamin ketika itu, bahwa liberalisme dan demokrasi Barat merupakan faham yang harus ditolak. Negara Indonesia yang akan dilahirkan menurutnya harus dibentuk berdasar atas "keputusan bermusyawarah" dan di dalamnya selalu mewujudkan semangat permusyawaratan yang pada dasarnya merupakan pengejawantahan perintah Tuhan yang mewajibkan umatnya untuk "bermusyawarah untuk urusan umum". ${ }^{24}$

Yamin juga menyebut "dasar perwakilan" sebagai karakter "kebudayaan politik" Indonesia. Dijelaskan pula bahwa sifat perwakilan telah menjadi asas pemerintahan masyarakat Indonesia selama ribuan tahun di desa, negeri, dusun, marga dan lain-lain. "Suatu Negara Indonesia yang akan dibentuk..." kata Yamin, “...tentulah tidak menjadi sambungan jiwa tatanegara masyarakat apabila sifat perwakilan tidak dipakai." Menurut Yamin, "dasar permusyawaratan dan perwakilan" itulah yang menjadi karakter khas "demokrasi Indonesia". Dalam bayangannya, demokrasi yang dijalankan di Indonesia berbentuk perkumpulan para perwakilan rakyat untuk bermusyawarah tentang beragam urusan-urusan umum. Selanjutnya, Yamin juga menjelaskan bahwa menurut peradaban Indonesia, permusyawaratan dan perwakilan itu adalah di bawah pimpinan hikmah-kebijaksanaan (dari) yang bermusyawarah atau berkumpul

23 Saafroedin Bahar and Nannie Hudawati, Risalah Sidang Badan Penyelidik Usaha Persiapan Kemerdekaan Indonesia (BPUPKI)-Panitia Persiapan Kemerdekaan Indonesia (PPKI) 22 Mei 1945-22 Agustus 1945 (Jakarta, 1998). 22.

24 Bahar and Hudawati. 18. 
dalam persidangan. Yang dimaksud dengan "hikmah kebijaksanaan yang menjadi pimpinan kerakyatan Indonesia” itu, menurut Yamin, “... ialah rasionalisme yang sehat, karena telah melepaskan diri dari anarki, liberalisme dan semangat pejajahan". ${ }^{25}$

Selain M. Yamin, pendiri bangsa lainnya, yakni Soepomo dalam sidang BPUPKI ketika itu membandingkan dasar ketatanegaraan di Eropa Barat dan Amerika, Uni Soviet, Jerman era Nazi dan juga Jepang. Pertama-tama Soepomo membandingkan ketatanegaraan di Eropa Barat dan Amerika. Dikatakan oleh Soepomo bahwa ketatanegaraan Eropa Barat dan Amerika didasarkan atas paham individualisme dan liberalisme yang mencakup berbagai bidang kehidupan seperti ekonomi, sosial, politik dan sebagainya. ${ }^{26}$ Karakter seperti itu menurut Soepomo pada kenyataannya memisahkan individu dari masyarakat serta membuat individu menjadi terasing dengan sekitarnya serta berhadapan vis a vis dengan negara. Sistem yang demikian itu pada akhirnya akan menyebabkan lahirnya imperialisme dan sistem memeras (uitbultings system) serta "membuat kacau-balaunya dunia lahir dan batin". ${ }^{27}$

Soepomo membandingkan hukum kenegaraan Uni Soviet. Menurutnya, hukum kenegaraan Uni Soviet didasarkan atas teori kelas (class theory) yang digagas Marx, Engels dan Lenin yang menganggap negara sebagai alat penindasan kelas borjuis penguasa ekonomi terhadap kelas pekerja (proletar) yang posisi ekonominya lebih lemah. Karenanya, Marxisme berorientasi pada penguasaan negara

25 Bahar and Hudawati. 19-22

26 "Paham Tersebut Pada Prinsipnya Merupakan Turunan Atas Ajaran Teori Indovidualistik Yang Diajarkan Oleh Thomas Hobbes Dan John Locke (Abad Ke 17), J.J Rousseau (Abad Ke 18), Herbert Spencer (Abad Ke 19) Dan H.J Laski (Abad Ke 20).," n.d.

27 Bahar and Hudawati, Risalah Sidang Badan Penyelidik Usaha Persiapan Kemerdekaan Indonesia (BPUPKI)-Panitia Persiapan Kemerdekaan Indonesia (PPKI) 22 Mei 1945-22 Agustus 1945. 52. oleh kelas pekerja dalam sistem "diktatur proletariat". Soepomo mengatakan bahwa sistem kediktatoran ini boleh jadi sesuai dengan tata sosial yang ada di Rusia, namun bertentangan dengan sifat masyarakat Indonesia yang asli. ${ }^{28}$

Lebih lanjut, Soepomo mengatakan bahwa sistem kenegaraan yang dianggap sesuai dengan corak masyarakat Indonesia adalah sistem kenegaraan nasionalis-sosialis totaliter seperti yang dipraktikkan Nazi Jerman dan sistem Kekaisaran Jepang. Sistem ini menurut Soepomo diilhami dari teori integralistik yang diajarkan Spinoza, Adam Muller, Hegel dan sejumlah pemikir lain. Teori ini dinilai Soepomo sebagai antitesa dua teori sebelumnya karena dalam teori integralistik, negara tidak untuk melayani individu dan bukan untuk kekuasaan satu golongan tertentu, melainkan kepentingan masyarakat seluruhnya sebagai persatuan. ${ }^{29}$

Dikatakan pula oleh Soepomo bahwa konsekuensi penolakan atas faham individualisme berujung pada penolakan terhadap sistem pemerintah parlemen dan sistem demokrasi Barat. Karenanya, Soepomo juga menolak sistem pemilihan pemimpin berdasarkan demokrasi Barat yang disebutnya sebagai “... sistem yang menyamakan manusia satu dengan lain seperti angka-angka belaka yang semua sama harganya". ${ }^{30}$ Hal senada dikemukakan Yamin yang mengatakan bahwa pemilihan pemimpin di seluruh tingkatan negara dari Pusat sampai daerah hendaknya "dipilih secara Timur dalam permusyawaratan yang disusun oleh rakyat". 31

Akhirnya, atas dasar konstruksi pemikiran yang demikian itulah kemudian melahirkan kelembagaan MPR sebagai penjelmaan seluruh rakyat Indonesia (Vertretungsorgan

\footnotetext{
28 Bahar and Hudawati.

29 Bahar and Hudawati.

30 Bahar and Hudawati.

31 Rully Chairul Azwar, "Kedaulatan Rakyat Dan
} Sosio-Demokrasi” (Yogyakarta, 2016). 
des Willens des Staatsvolkes) yang memegang kekuasaan tertinggi negara (Die gezaamte Staatgewalt kuueght allein bei de Majelis), ${ }^{32}$ yang kemudian diterjemahkan dalam bunyi Pasal 1 ayat (2) UUD 1945 yang menyatakan bahwa "Kedaulatan adalah di tangan rakyat, dan dilakukan sepenuhnya oleh Majelis Permusyawaratan Rakyat", dengan komposisi keanggotaan MPR terdiri atas anggota Dewan Perwakilan Rakyat, ditambah dengan utusanutusan dari daerah-daerah dan golongangolongan, ${ }^{33}$ serta memiliki kewenangan dalam menetapkan UUD 1945, menetapkan Garisgaris Besar Haluan Negara (GBHN), ${ }^{34}$ dan memilih Presiden serta Wakil Presiden dengan suara terbanyak. ${ }^{35}$ Terbentuknya kedudukan, kewenangan hingga komposisi/susunan keanggotaan MPR yang demikian itu, tidak lain merupakan hasil pengejawantahan faham cita negara integralistik yang semula diusulkan oleh Soepomo dan pada akhirnya disempurnakan dengan istilah cita negara kekeluargaan sebagai bentuk penolakan atas faham liberalisme dan demokrasi barat.

Dari penjelasan di atas, secara filosofis begitu terlihat bahwa ada suatu tujuan yang sangat mulia dari pendiri negara dalam membentuk kelembagaan MPR dan mendesain kewenangannya sedemikian rupa sehingga sejalan dengan kebudayaan politik di Indonesia. ${ }^{36}$ Pendiri negara menginginkan agar

32 Charles Simabura, Parlemen Indonesia: Lintasan Sejarah Dan Sistemnya (Yogyakarta: Rajawali Pers, 2011). v.

33 Pasal 2 ayat (1) "Undang-Undang Dasar Negara Republik Indonesia Tahun 1945.”

34 Pasal 3 "Undang-Undang Dasar Negara Republik Indonesia Tahun 1945."

35 Pasa; 6 ayat (2) “Undang-Undang Dasar Negara Republik Indonesia Tahun 1945."

36 Dari perdebatan yang terjadi, terlihat pula pendiri negara meyakini bahwa Indonesia harus didirikan berdasarkan tradisi asli bangsa Indonesia, tetapi tradisi itu juga harus disesuaikan dengan susunan negara-bangsa dan sistem demokrasi modern. Mereka meyakini pula bahwa demokrasi yang sesuai dengan tradisi asli bangsa Indonesia adalah demokrasi dengan keadilan sosial, yakni masyarakat Indonesia terbebas dari dampak negatif atas pemberlakuan paham liberalisme dan demokrasi Barat. Untuk mewujudkan keinginan tersebut, dibentuklah kelembagaan MPR dan menjadikannya sebagai "rumah rakyat" tempat "seluruh masyarakat" Indonesia berkumpul. Oleh karena hakekat MPR pada prinsipnya merupakan "rumah rakyat", di sanalah kemudian dijadikan tempat "seluruh rakyat untuk bermusyawarah" dalam segala hal yang berdampak langsung dengan kepentingan umum, seperti bermusyawarah untuk mencari pemimpin negara, menetapkan garis-garis besar haluan negara agar terwujudnya tujuan nasional yang sepenuhnya ditujukan untuk kesejahteraan masyarakat, membentuk dan menetapkan aturan dasar yang memberikan perlindungan terhadap hak-hak dasar warga negara, menata kelembagaan negara, melakukan pembatasan kekuasaan, serta menjadi tempat untuk bermusyawarah dalam menyelesaikan berbagai permasalahan ketatanegaraan yang menyangkut kepentingan negara dan masyarakat Indonesia.

Pada fase inilah kemudian secara filosofis pembentukan Undang-Undang tentang MPR menjadi penting untuk segera diwujudkan. Meskipun saat ini MPR tidak lagi berkedudukan sebagai lembaga tertinggi negara dalam relasi kekuasaan antar lembaga negara di Indonesia, hal tersebut tidak merubah status dan hakekatnya sebagai rumah rakyat. Oleh karena itu, kehadiran Undang-Undang tentang MPR merupakan suatu bentuk tekat negara Indonesia untuk menjaga hakekat, eksistensi dan keistimewaan MPR sebagai rumah rakyat. Dengan kata lain, melekatkan pengaturan kelembagaan dan kewenangan MPR ke dalam

suatu demokrasi yang berdasar pada faham kolektivisme yang terwujud dalam sistem permusyawaratan dan perwakilan. Konsep ini diungkapkan dalam prinsip ke 4 Pancasila yang berbunyi: "Kerakyatan yang dipimpin oleh hikmah kebijaksanaan dalam permusyawaratan perwakilan." Baca: Aidul Fitriciada Azhari, Rekonstruksi Tradisi Bernegara Dalam UUD 1945 (Yogyakarta: Genta Publishing, 2014). 68. 
undang-undang yang juga mengatur mengenai lembaga negara lainnya sama saja seperti halnya kita menafikkan keistimewaan dari kelembagaan MPR sebagai rumah rakyat di Indonesia.

\section{Urgensi Yudiris Pembentukan UU MPR}

Berbicara mengenai urgensitas secara yuridis pembentukan Undang-Undang tentang MPR dalam sistem ketatanegaraan Indonesia, tentu tidak dapat kita lepaskan kaitanya dengan bunyi Pasal 2 ayat (1) UUD NRI 1945 hasil perubahan ke-4. Dalam pasal tersebut, dikatakan bahwa MPR terdiri atas anggota DPR dan DPD yang dipilih melalui pemilihan umum dan diatur lebih lanjut dengan undang-undang. Jika dicermati, setidaknya terdapat tiga point penting dalam rumusan Pasal 2 ayat (1) tersebut; Pertama, bahwa keanggotaan MPR teridiri dari anggota DPR dan DPD; Kedua, bahwa anggota DPR dan DPD yang akan menjadi bagian dari keanggotaan MPR haruslah dipilih melalui pemilu; dan ketiga bahwa pengaturan lebih lanjut mengenai segala hal berkenaan dengan MPR diatur "dengan" undang-undang.

Lebih jauh dari pada itu, rumusan yang demikian, pada dasarnya dapat kita ketahui bahwa terjadi suatu atribusi kewenangan dari UUD NRI 1945 kepada pembentuk undangundang untuk membentuk undang-undang yang mengatur secara rigid berkenaan dengan kelembagaan MPR. Oleh karena nomenklatur yang digunakan di dalam UUD NRI 1945 adalah “...diatur dengan...", maka pengaturan mengenai kelembagaan MPR sebagaimana dimaksud haruslah diatur di oleh undangundang tersendiri.

Dengan kata lain, tidak dibenarkan jika pengaturan mengenai kelembagaan MPR dilekatkan kedalam undang-undang yang mengatur mengenai lembaga negara lainnya seperti halnya yang kini terjadi. Hari ini, fakta menunjukkan bahwa pengaturan kelembagaan
MPR diatur dalam undang-undang yang juga mengatur mengenai lembaga negara lainnya yakni DPR, DPD dan DPRD.

Mengutip pendapat Prof. Dr. Soenjono Dardjiwidjo yang notabenenya merupakan pakar linguistik dari Universitas Atmajaya, dikatakan bahwa apabila digunakan frase "di dalam undang-undang" pada suatu produk peraturan perundang-undangan, maka berarti masalah yang dikemukakan pada peraturan perundang-undangan tersebut haruslah diatur di dalam suatu undang-undang. Sementara apabila digunakan frase "dengan undang-undang" pada suatu produk peraturan perundang-undangan, maka berarti masalah yang dikemukakan pada peraturan perundang-undangan tersebut haruslah diatur dengan undang-undang yang terpisah dari pengaturan lainnya, dan undangundang sebagaimana dimaksud haruslah berdiri sendiri. ${ }^{37}$ Pemahaman yang demikian juga dibenarkan jika kita menggunakan penafsiran gramatikal terhadap rumusan sebagaimana dimaksud. $^{38}$

Dari pandangan tersebut, sebenarnya dapat diketengahkan bahwa secara yuridis pembentukan Undang-undang tentang MPR menjadi penting untuk diwujudkan dalam rangka melaksanakan amanat Pasal 2 ayat (1) UUD NRI 1945. Tidak hanya itu, pembentukan Undang-undang tentang MPR juga merupakan upaya untuk menegakkan tertib pembentukan peraturan perundang-undangan dalam bingkai negara hukum Indonesia.

Dalam negara hukum, tertib pembentukan peraturan perundang-undangan merupakan keniscayaan yang tidak dapat dinafikan. Hal ini pada akhirnya membuat pembentukan peraturan perundang-undangan haruslah mem-

37 "Bahasa Hukum," Hukum Online, 2007, http://www.hukumonline.com/berita/baca/hol15982/ menyimak-perbedaan-kata-dengan-dan-dalam.

38 Jimly Asshiddiqie, "Pengantar Ilmu Hukum Tata Negara Jilid 1," Buku Ilmu Hukum Tata Negara 1 (2006): 200. 
perhatikan kaidah-kaidah pembentukan peraturan perundang-undangan yang baik dan benar. Kaidah tersebut salah satunya adalah soal kewenangan/perintah pengaturan dan dimana materi peraturan tersebut harus diletakkan. Tidak dibenarkan tentunya apabila proses pembentukan peraturan perundang-undangan dilakukan tanpa ada kewenangan/perintah pengaturan. Begitupun sebaliknya, sekalipun ada kewenangan/perintah pengaturan, maka pengaturan terhadap materi peraturan perundang-undangan tersebut haruslah diletakkan dengan/dalam instrumen hukum yang tepat.

Berkenaan dengan hal tersebut, sejarah mencatat bahwa ketidaktepatan meletakkan materi muatan peraturan perundang-undangan dalam suatu instumen hukum pernah terjadi pada tahun 2002-2006. Ketika itu, pembentuk undang-undang melekatkan pengaturan mengenai pembentukan Pengadilan Tindak Pidana Korupsi kedalam undang-undang Komisi Pemberantasan Korupsi yang kemudian hal ini dianulir oleh Mahkamah Konstitusi (MK) melalui Putusan Nomor 012-016-019/ PUU-IV/2006.

Dalam putusannya, MK menyatakan bahwa Pasal 53 Undang-Undang Nomor 30 Tahun 2002 tentang Komisi Pemberantasan Korupsi bertentangan dengan pasal 24A ayat (5) UUD NRI 1945 yang berbunyi "Susunan, kedudukan, keanggotaan dan hukum acara Mahkamah Agung serta badan peradilan dibawahnya diatur dengan undang-undang". Menurut MK, jika ditinjau dari segi teknik perundang-undangan, penggunaan frasa "diatur dengan undang-undang" pada Pasal 24A ayat (5) UUD NRI 1945 memberikan arah bahwa pembentukan Pengadilan Tindak Pidana Korupsi haruslah diatur dengan undangundang sendiri. ${ }^{39}$ Oleh karena dalam praktiknya pembentuk undang-undang justru melekatkan

39 "Putusan Mahkamah Konstitusi Nomor Nomor 012-016-019/PUU-IV/2006,” n.d. 283. pengaturan mengenai pembentukan Pengadilan Tindak Pidana Korupsi kedalam UndangUndang tentang KPK, maka dengan suara mayoritas kemudian $\mathrm{MK}$ berpendapat dan menyatakan bahwa pembentukan Pengadilan Tindak Pidana Korupsi sebagaimana diatur dalam Undang-undang tentang KPK tidak sejalan dengan Pasal 24A ayat (5) UUD NRI 1945.

Sejarah pengaturan kelembagaan yang tidak ideal ini setidaknya dapat dijadikan pelajaran bagi pembentuk undang-undang untuk menempatkan suatu materi muatan peraturan perundang-undangan dengan/dalam instrumen hukum yang tepat, begitupun terhadap pengaturan mengenai kelembagaan MPR. Dengan kata lain, fakta sejarah Pengadilan Tindak Pidana Korupsi dapat menjadi pelajaran bagi pembentuk undang-undang untuk selalu menegakkan tertib pembentukan peraturan perundang-undangan dalam bingkai negara hukum Indonesia.

\section{Urgensi secara Sosiologis-Politik Pembentukan UU MPR}

Tidak ada tingkah laku manusia dalam kehidupan bermasyarakat yang lepas dari aturan hukum. Oleh karenanya tidak berlebihan kalau dikatakan dimana ada masyarakatdisitu ada hukum (ubi societas, ibi ius). Selain itu, hukum dapat berfungsi sebagai objek pembangunan dalam rangka mewujudkan suatu hukum yang ideal, yang sesuai dengan nilai-nilai yang hidup di masyarakat. Ini sesuai dengan pandangan dari aliran sociological jurisprudence, bahwa hukum yang baik adalah hukum yang sesuai dengan nilai-nilai yang tumbuh dan hidup dalam masyarakat. Supaya hukum sejalan dengan nilai-nilai yang hidup dalam kehidupan masyarakat tersebut maka hukum tersebut harus digali dari masyarakat itu sendiri. ${ }^{40}$

40 Hariyanto Hariyanto, "Pembangunan Hukum Nasional Berdasarkan Nilai-Nilai Pancasila," Volksgeist: 
Secara normatif, urgensi sosiologis-politik dapat dipahami sebagai suatu pertimbangan atau alasan yang menggambarkan bahwa peraturan yang dibentuk adalah untuk merespon kebutuhan empiris dan fakta politik yang terjadi di masyarakat terhadap suatu permasalahan tertentu.

Kaitannya dengan pembentukan Undangundang tentang MPR, perlu untuk diketahui bahwa ketika muncul wacana mengenai perubahan terhadap Undang-Undang Nomor 17 Tahun 2014 tentang Majelis Permusyawaratan Rakyat, Dewan Perwakilan Rakyat, Dewan Perwakilan Daerah, dan Dewan Perwakilan Rakyat Daerah yang selanjutnya disebut dengan UU MD3 sebagaimana telah diubah beberapa kali, terakhir Undang-Undang Nomor 13 Tahun 2019 tentang Perubahan Ketiga Atas Undang-Undang Nomor 17 Tahun 2014 tentang MD3, ketika itu pula kegaduhan politik dapat dikatakan selalu terjadi.

Hal ini dikarenakan perubahan UU MD3 selalu diidentikkan dengan upaya "bagi-bagi kekuasaan" diantara partai politik yang duduk dikursi parlemen. Kegaduhan politik terebut praktis mengakibatkan instabilitas politik nasional, yang baik secara langsung maupun tidak langsung berimplikasi pada lembaga negara yang menjadi obyek perubahan ataupun lembaga-lembaga negara lain seperti MPR yang juga diatur di dalam UU tersebut.

Olehkarenaitu, dalamperspektifsosiologispolitik dapat diketengahkan bahwa pemisahan pengaturan kelembagaan dan kewenangan MPR dari UU MD3 menjadi penting untuk dilakukan dalam upaya meminimalisir akibat negatif yang akan dirasakan oleh kelembagaan MPR setiapkali dilakukannya perubahan terhadap UU MD3. Selain itu, dalam lingkup yang lebih luas, pemisahan pengaturan mengenai lembaga negara yang diatur dalam UU MD3 juga penting untuk dilakukan dalam

Jurnal Ilmu Hukum Dan Konstitusi 1, no. 1 (June 7, 2018): 54, https://doi.org/10.24090/volksgeist.v1i1.1731. rangka meminimalisir terjadinya kegaduhan politik yang berakibat pada instabilitas politik nasional ketika dilakukan perubahan terhadap undang-undang sebagaimana dimaksud yang erat kaitannya dengan "bagi-bagi kekuasaaan".

\section{Catatan Terhadap Proses Pembentukan UU MPR}

Setelah diketahui bahwa wacana pembentukan Undang-Undang tentang MPR dalam sistem ketatanegaraan Indonesia memiliki urgensi baik secara filosofis, yuridis maupun sosiologis-politik, namun dalam proses pembentukan nantinya haruslah memperhatikan beberapa hal yang tidak boleh dilupakan. Pertama, materi muatan di dalam ius constituendum Undang-Undang tentang MPR haruslah mampu menjaga hakikat, eksistensi dan keistimewaan MPR sebagai rumah rakyat. Ini menjadi penting sebab bagaimanapun satu dari sekian urgensi pengaturan kelembagaan MPR dengan undang-undang tersendiri yakni sebagai upaya dalam mewujudkan hal tersebut.

Kedua, selain harus mampu menjaga hakikat, eksistensi dan keistimewaan MPR sebagai rumah rakyat, materi muatan di dalam ius constituendum Undang-Undang tentang MPR haruslah mencerminkan beberapa asas yang mendukung tujuan dari pembentukan undang-undang a quo. Setidaknya beberapa asas yang perlu diperhatikan yakni:

1. asas kebangsaan yang menyatakan bahwa materi muatan peraturan perundangundangan harus mencerminkan sifat dan watak bangsa indonesia yang majemuk dengan tetap menjaga prinsip Negara Kesatuan Republik Indonesia. ${ }^{41}$

2. Asas kenusantaraan yang menyatakan bahwa bahwa setiap materi muatan peraturan perundang-undangan senantiasa

41 Pasal 6 ayat 1 huruf c "Undang-Undang Nomor 12 Tahun 2011 Tentang Pembentukan Peraturan Perundang-Undangan," n.d. 
memperhatikan kepentingan seluruh wilayah Indonesia dan materi muatan peraturan perundang-undangan yang dibuat di daerah merupakan bagian dari sistem hukum nasional yang berdasarkan Pancasila dan Undang-Undang Dasar Negara Republik Indonesia Tahun 1945. ${ }^{42}$

3. Asas Bhineka Tunggal Ika yang menyatakan bahwa materi muatan peraturan perundang-undangan harus memperhatikan keragaman penduduk, agama, suku dan golongan, kondisi khusus daerah serta budaya dalam kehidupan bermasyarakat, berbangsa, dan bernegara. ${ }^{43}$

4. Asas kesamaan kedudukan dalam hukum dan pemerintahan yang menyatakan bahwa setiap materi muatan peraturan perundangundangan tidak boleh memuat hal yang bersifat membedakan berdasarkan latar belakang, antara lain, agama, suku, ras, golongan, gender, atau status sosial. ${ }^{44}$

5. asas kepastian hukum yang menyatakan bahwa setiap materi muatan peraturan perundang-undangan tidak boleh memuat materi-materi yang bersifat multitafsir. ${ }^{45}$

Ketiga, pembentukan Undang-Undang tentang MPR harus dilakukan dengan berdasarkan pada asas pembentukan peraturan perundang-undangan yang baik sebagaimana diatur dalam Pasal 5 Undang-Undang Nomor 12 Tahun 2011 tentang Pembentukan Peraturan Perundang-undangan, yakni:

1. Asas kejelasan tujuan yang menyatakan bahwa setiap pembentukan peraturan

42 Pasal 6 ayat (1) huruf e "Undang-Undang Nomor 12 Tahun 2011 Tentang Pembentukan Peraturan Perundang-Undangan."

43 Pasal 6 ayat (1) huruf f "Undang-Undang Nomor 12 Tahun 2011 Tentang Pembentukan Peraturan Perundang-Undangan."

44 Pasal 6 ayat (1) huruf $\mathrm{h}$ "Undang-Undang Nomor 12 Tahun 2011 Tentang Pembentukan Peraturan Perundang-Undangan."

45 Pasal 6 ayat (1) huruf i "Undang-Undang Nomor 12 Tahun 2011 Tentang Pembentukan Peraturan Perundang-Undangan.” perundang-undangan harus mempunyai tujuan yang jelas yang hendak dicapai. ${ }^{46}$

2. Asas kelembagaan atau pejabat pembentuk yang tepat yang menyatakan bahwa setiap jenis peraturan perundang-undangan harus dibuat oleh lembaga negara atau pejabat pembentuk peraturan Perundang-undangan yang berwenang. peraturan perundangundangan tersebut dapat dibatalkan atau batal demi hukum apabila dibuat oleh lembaga negara atau pejabat yang tidak berwenang. ${ }^{47}$

3. Asas kesesuaian antara jenis, hierarki, dan materi muatan yang menyatakan bahwa bahwa dalam pembentukan peraturan perundang-undangan harus benar-benar memperhatikan materi muatan yang tepat sesuai dengan jenis dan hierarki peraturan perundang-undangan. ${ }^{48}$

4. Asas dapat dilaksanakan yang menyatakan bahwa bahwa setiap pembentukan peraturan perundang-undangan harus memperhitungkan efektivitas peraturan perundang-undangan tersebut di dalam masyarakat, baik secara filosofis, sosiologis, maupun yuridis. ${ }^{49}$

5. Asas kedayagunaan dan kehasilgunaan yang menyataan bahwa setiap peraturan perundangundangan dibuat karena memang benar-benar dibutuhkan dan bermanfaat dalam mengatur kehidupan bermasyarakat, berbangsa, dan bernegara. ${ }^{50}$

46 Pasal 5 huruf a "Undang-Undang Nomor 12 Tahun 2011 Tentang Pembentukan Peraturan PerundangUndangan."

47 Pasal 5 huruf b "Undang-Undang Nomor 12 Tahun 2011 Tentang Pembentukan Peraturan PerundangUndangan."

48 Pasal 5 huruf c "Undang-Undang Nomor 12 Tahun 2011 Tentang Pembentukan Peraturan PerundangUndangan."

49 Pasal 5 huruf d "Undang-Undang Nomor 12 Tahun 2011 Tentang Pembentukan Peraturan PerundangUndangan."

50 Pasal 5 huruf e "Undang-Undang Nomor 12 Tahun 2011 Tentang Pembentukan Peraturan Perundang- 
6. Asas kejelasan rumusan yang menyatakan bahwa setiap peraturan perundangundangan harus memenuhi persyaratan teknis penyusunan peraturan perundangundangan, sistematika, pilihan kata atau istilah, serta bahasa hukum yang jelas dan mudah dimengerti sehingga tidak menimbulkan berbagai macam interpretasi dalam pelaksanaannya. ${ }^{51}$

7. Asas keterbukaan yang menyatakan bahwa dalam Pembentukan Peraturan Perundangundangan mulai dari perencanaan, penyusunan, pembahasan, pengesahan atau penetapan, dan pengundangan bersifat transparan dan terbuka. Dengan demikian, seluruh lapisan masyarakat mempunyai kesempatan yang seluas-luasnya untuk memberikan masukan dalam Pembentukan Peraturan Perundang-undangan. ${ }^{52}$

Keempat, pembentukan Undang-Undang tentang MPR harus mengkedepankan partisipasi publik. Berkenaan dengan hal ini, selain merupakan sebuah hak yang dimiliki masyarakat sebagaimana diamanatkan dalam Pasal 96 Undang-Undang Nomor 12 Tahun 2011 tentang Pembentukan Peraturan Perundang-undangan, keterlibatan publik mutlak dibutuhkan dalam pembentukan peraturan perundang-undangan khususnya Undang-Undang tentang MPR agar materi muatan di dalam undang-undang tersebut benar-benar dapat mengakomodir kepentingan publik. Tidak hanya itu, partisipasi publik juga dibutuhkan dalam rangka mengontrol agar proses pembentukan peraturan tersebut sejalan dengan tujuan pembentukannya dan berjalan diatas koridor yang telah ditentukan oleh peraturan perundang-undangan. Bagaimanapun

Undangan."

51 Pasal 5 huruf f "Undang-Undang Nomor 12 Tahun 2011 Tentang Pembentukan Peraturan PerundangUndangan."

52 Asal 5 huruf g "Undang-Undang Nomor 12 Tahun 2011 Tentang Pembentukan Peraturan PerundangUndangan."
MPR merupakan rumah rakyat, oleh karena itu menjadi keharusan bahwa pembentukan peraturan mengenai kelembagaan tersebut haruslah melibatkan rakyat.

Rakyat yang merupakan penjelmaan sipil masyarakat, berfungsi sebagai kontrol atas pelaksanaan kekuasaan, baik dalam pembentukan kekuasaan kehakiman maupun kekuasaan untuk menjalankan pemerintahan. Ketika publik lingkup dalam kehidupan masyarakat, terutama di bawah kekuasaan payung hukum dan menjunjung tinggi nilainilai demokrasi menjadi kosong, kering dari gagasan ius konstituendum atau ideide konstruktif untuk setiap negara bagian administrasi, itu akan kehilangan filosofi negara hidup berdasarkan Pancasila. Badan legislatif masih saja mewakili dan menjalankan kepentingan pribadi dan mencari penawar tertinggi untuk undang-undang yang digunakan sebagai perdagangan komoditas. ${ }^{53}$

\section{PENUTUP}

Berdasarkan uraian pembahasan sebagaimana telah dijelaskan, dapat diketahui bahwa pembentukan Undang-Undang tentang MPR memiliki urgensi secara filosofis, yuridis maupun sosiologis-politik. Hal ini kemudian membuat DPR perlu untuk mengusulkan suatu RUU tentang MPR dalam program legislasi nasional untuk dapat dibahas dan disetujui bersama Presiden. Namun begitu, terdapat beberapa hal yang perlu diperhatikan dan tidak boleh dilupakan dalam proses pembentukan undang-undang tersebut, yakni berkenaan dengan materi muatan maupun proses pembentukan. Oleh karena itu, apabila proses pembentukan Undang-Undang tentang

53 Hariyanto, Kadar Pamuji, and Tedi Sudrajat, "The Ideals of Pancasila Law in the Process of Forming Legislation" (The 2nd International Conference of Law, Government and Social Justice (ICOLGAS 2020), Atlantis Press, 2020), 171, https://doi.org/10.2991/ assehr.k.201209.281. 
MPR dapat terealisasi, dibutuhkan keterlibatan semua pihak agar tujuan dari pembentukannya dapat tercapai.

\section{DAFTAR PUSTAKA}

Asshiddiqie, Jimly. Konstitusi Dan Konstittusionalisme Indonesia. Jakarta: Sekretariat Jenderal dan Kepaniteraan MK, 2006.

_. "Pengantar Ilmu Hukum Tata Negara Jilid 1." Buku Ilmu Hukum Tata Negara 1 (2006): 200.

- Perihal Undang-Undang. Jakarta: Konstitusi Press, 2006.

Astomo, Putera. Hukum Tata Negara Teori Dan Praktek. Yogyakarta: Thafa Media, 2014.

Ayu Anastasia Wierdarini, Putu. "Tinjauan Yuridis Terhadap Pengembalian Kewenangan Istimewa Majelis Permusyawaratan Rakyat Melalui Perubahan Undang-Undang Dasar Negara Republik Indonesia Tahun 1945." Jurnal Yuridis 5, no. 1 (2018).

Bahar, Saafroedin, and Nannie Hudawati. Risalah Sidang Badan Penyelidik Usaha Persiapan Kemerdekaan Indonesia (BPUPKI)-Panitia Persiapan Kemerdekaan Indonesia (PPKI) $22 \mathrm{Mei}$ 1945-22 Agustus 1945. Jakarta, 1998.

Hukum Online. "Bahasa Hukum," 2007. http:// www.hukumonline.com/berita/baca/ hol15982/menyimak-perbedaan-katadengan-dan-dalam.

Bakar Ismail, Muhammad. Al-Qawa'idh AlFiqhiyyah Baina Al-Ashalati Wa AlTaujih. Kairo: Darul Manar, 1996.

Chairul Azwar, Rully. "Kedaulatan Rakyat Dan Sosio-Demokrasi.” Yogyakarta, 2016.

Fitriciada Azhari, Aidul. Rekonstruksi Tradisi Bernegara Dalam UUD 1945. Yogyakarta: Genta Publishing, 2014.
Hariyanto, Hariyanto. "Pembangunan Hukum Nasional Berdasarkan Nilai-Nilai Pancasila." Volksgeist: Jurnal Ilmu Hukum Dan Konstitusi 1, no. 1 (June 7, 2018): 53-63. https://doi.org/10.24090/volksgeist.v1i1.1731.

Hariyanto, Kadar Pamuji, and Tedi Sudrajat. "The Ideals of Pancasila Law in the Process of Forming Legislation," 16673. Atlantis Press, 2020. https://doi. org/10.2991/assehr.k.201209.281.

Huda, Ni'matul. Lembaga Negara Dalam Masa Transisi Demokrasi. Yogyakarta: UII Press, 2007.

Mahfud MD, Moh. Perdebatan Hukum Tata Negara Pasca Amandemen Konstitusi. Cet 1. Jakarta: Raja Grafindo Persada, 2010.

"Paham Tersebut Pada Prinsipnya Merupakan Turunan Atas Ajaran Teori Indovidualistik Yang Diajarkan Oleh Thomas Hobbes Dan John Locke (Abad Ke 17), J.J Rousseau (Abad Ke 18), Herbert Spencer (Abad Ke 19) Dan H.J Laski (Abad Ke 20).," n.d.

"Putusan Mahkamah Konstitusi Nomor Nomor 012-016-019/PUU-IV/2006," n.d.

Ramadani, Rizki. "Gagasan Penyempurnaan Lembaga Majelis Permusyawaratan Rakyat Republik Indonesia Dalam Sistem Parlemen Dua Kamar." Pleno Jure 9, no. 1 (2020): 1-15. https://doi.org/10.37541/ plenojure.v9i1.305.

Saifudin, Saifudin, and Dessy Ariani. "Kajian Yuridis Eksistensi Dan Materi Ketetapan Majelis Permusyawaratan Rakyat Republik Indonesia Dalam Hirarki PerundangUndangan Di Indonesia.” Jurnal Hukum Ius Quia Iustum 22, no. 1 (2015): 142-62. https://doi.org/10.20885/iustum.vol22. iss1.art7. 
Simabura, Charles. Parlemen Indonesia: Lintasan Sejarah Dan Sistemnya. Yogyakarta: Rajawali Pers, 2011.

Soedijarto. "Implikasi Ajaran Pendiri Republik (Bung Karno) Dan Budaya Politik Indonesia Terhadap Amandemen UUD 1945." Yogyakarta, 2016.

Solly Lubis, M. Landasan Dan Teknik Perundang-Undangan. Bandung: CV Mandar Maju, 1989.

"Undang-Undang Dasar Negara Republik Indonesia Tahun 1945," n.d.
"Undang-Undang Nomor 12 Tahun 2011 Tentang Pembentukan Peraturan PerundangUndangan," n.d.

"Undang-Undang Nomor 16 Tahun 1969 Tentang Susunan Dan Kedudukan Majelis Permusyawaratan Rakyat, Dewan Perwakilan Rakyat, Dan Dewan Perwakilan Rakyat Daerah," n.d.

"Undang-Undang Nomor 22 Tahun 2003 Tentang Susunan Dan Kedudukan MPR, DPR, DPD Dan DPRD," n.d. 